With the POUM

\title{
International volunteers on the Aragon Front (1936-1937)
}

\section{Amb el POUM. Voluntaris internacionals en el Front d'Aragó (1936-1937)}

\author{
Andy Durgan \\ Doctor en Història \\ London University \\ Senate House \\ Malet Street, London WC1E 7HU \\ \andydurgan@gmail.com
}

Rebut: 09/02/2018

Acceptat: 20/02/2018

\section{Resum}

Mentre que la història de les Brigades Internacionals està ben documentada, es coneix poc sobre els centenars de voluntaris estrangers que van lluitar amb les milícies obreres. Aquest article proporciona un resum dels orígens i característiques dels mes o menys sis-cents milicians internacionals que lluitaven amb el POUM durant els primers deu mesos de la Guerra Civil. Es contrast seva experiència amb la versió trobada en Homenatge a Catalunya de George Orwell, examinant tant el seu paper militar com la seva subseqüent destí després de la il-legalització del partit al juny 1937 i la dissolució de les seves milícies. Calumniats com "agents del feixisme», dotzenes d'aquests voluntaris van ser detinguts. No obstant això altres seguien Iluitant amb altres unitats, incloent les Brigades Internacionals. Finalment, l'article examina la sort d'alguns d'aquests voluntaris com a combatents i víctimes a la Segona Guerra Mundial.

Paraules clau: Front d'Aragó, POUM, Voluntaris Internacionals

\section{Abstract}

While the history of the International Brigades is well documented, little is known about the hundreds of foreign volunteers who fought with the workers' militias. This article provides an overview of the origins and characteristics of the six hundred or so international militia who fought with the POUM on the Aragon front during the first ten months of the Civil War. It contrasts their experience with the view provided in George Orwell's Homage to Catalonia, looking at both their military role and their subsequent fate once the POUM was illegalised in June in 1937 and its militia disbanded. Slandered as "fascist agents», dozens of these foreign volunteers were arrested. However, others 
would continue to fight in other units, including the International Brigades. Finally, the article examines the destiny of some of these volunteers as combatants and victims in the Second World War.

Keywords: Aragon Front, POUM, International Volunteers

\section{Sumari}

1. The International Group; 2 . The Volunteers; 3. The Lenin Division; 4. Orwell and the ILP Contingent; 5 . The Shock Battalion; 6 . The $29^{\text {th }}$ Division; 7. Repression and counterrevolution; 8 . The struggle continues

During the Spanish Civil War international volunteers, albeit a small minority of the Popular Army, played an important role as shock troops in defence of the Republic. There is an extensive literature relating to the 32,000 foreigners who fought with the International Brigades. However little is known about the hundreds of other international volunteers who remained in the workers' militias after the formation of the Brigades in October 1936.

In the case of the Partido Obrero de Unificación Marxista, George Orwell's Homage to Catalonia is the principle account of the experience of these volunteers. Orwell's text has shaped critical opinion about the revolution, the role of the Communists and the realities of life at the font. However, given the nature of his book and the circumstances it was written in, its scope is inevitably limited. The other six hundred or so foreigners who fought with the POUM have largely remained in Orwell's shadow. Moreover, research into the experience of these volunteers is hindered by the limited and extremely dispersed nature of archival material or its complete absence.

The motivations and origins of the POUM's foreign combatants on the Aragon front during the first ten months of the war were similar to those who made up the far more numerous International Brigades. Both paid a high price in the struggle against fascism. ${ }^{1}$ The principal, and terrible, difference between the two forces was that rather than be treated as heroes the POUM's foreign combatants would be subject to a campaign of vilification as «agents of fascism».

1. It has been estimated that a third of the International Brigaders died ÁLVAREZ, S., Historia política y military de las Brigadas Internacionales (Madrid 1996) pp398-399; around a hundred of the POUM foreign contingent fell in combat according to Victor ALBA, El Marxismo en España (1919-1939) tomo II (Mexico 1973) p369. 


\section{The International Group}

With the defeat of the military rising in Catalonia, the workers' organisations hurriedly formed militias to march on Zaragoza and Aragon, which was in fascist hands. The first column, headed by CNT leader Benaventura Durruti, left Barcelona on 23 July. Two more columns left the following day. The third of these columns was made up of members of the POUM and the newly formed Catalan Communist Party, the PSUC. After picking up more volunteers on the way, a specific POUM column was organised in the party's stronghold of Lleida before setting out for Eastern Aragon. ${ }^{2}$ Like other militia columns, the POUM militias established committees in the villages they occupied, collectivised land and dispensed revolutionary justice.

Among the thousand combatants in the first POUM column were around thirty foreign volunteers, mostly German and Italian anti-fascist refugees, already resident in Barcelona. Some were members of parties affiliated to the International Bureau of Revolutionary Socialist Unity (IBRSU), which had been founded by a dozen dissident communist and left socialist parties, including the forerunners of the POUM, in 1933. ${ }^{3}$ The IBRSU was highly critical of Stalinism and counter-posed the creation of a Workers' United against fascism to the Popular Front strategy, which they believed subordinated the working class to bourgeois democracy.

By 1936, Germans constituted the largest community of political refugees in Barcelona. They included members of the IBRSU affiliated German Socialist Workers' Party $(\mathrm{SAPD})^{4}$ and the German Opposition Communist Party (KPD-O). ${ }^{5}$ Both parties would play a prominent role in supporting the POUM, both at the front and in the rear. With the victory of the Popular Front in February 1936, more refugees had made their way to Barcelona, especially Italians; including several members of the Italian Maximalist Socialist Party

2. La Vanguardia 24.7.36; Avant! 26.7.36; the Column was initially commanded by Jordi Arquer and the Asturian miners' leader Manuel Grossi, with a former army sergeant Francesc Piquer as military advisor. Three more POUM columns would leave from Barcelona over the coming month: on 29 July, 8 August and 29 August; there were also two more columns organised from Lleida; columns from Tarragona, Castelló and Valencia left for the Teruel front

3. On the IBRSU see DURGAN, A., Comunismo, revolución y movimiento obrero en Cataluña 19201936. Los origins del POUM (Barcelona 2016) pp311-314.

4. The SAPD had split in 1931 with the SPD over its support of the right wing government and its failure to build a workers' united front against fascism.

5. The KPD(O)'s founding members had been expelled in 1928 from the KPD as supporters of Nickolai Bukharin; they also defended the need for an anti-fascist united front; under the impact to the Spanish Civil War they would evolve towards a militant anti Stalinism and in 1938 join the IBRSU. In Barcelona the largely Jewish KPD(O) group gravitated, like other refugees not associated with the KPD, around the kiosk in the Plaça Catalunya selling anti-fascist literature, ran by the $\mathrm{KPD}(\mathrm{O})$ members Ewald and Ella König. 


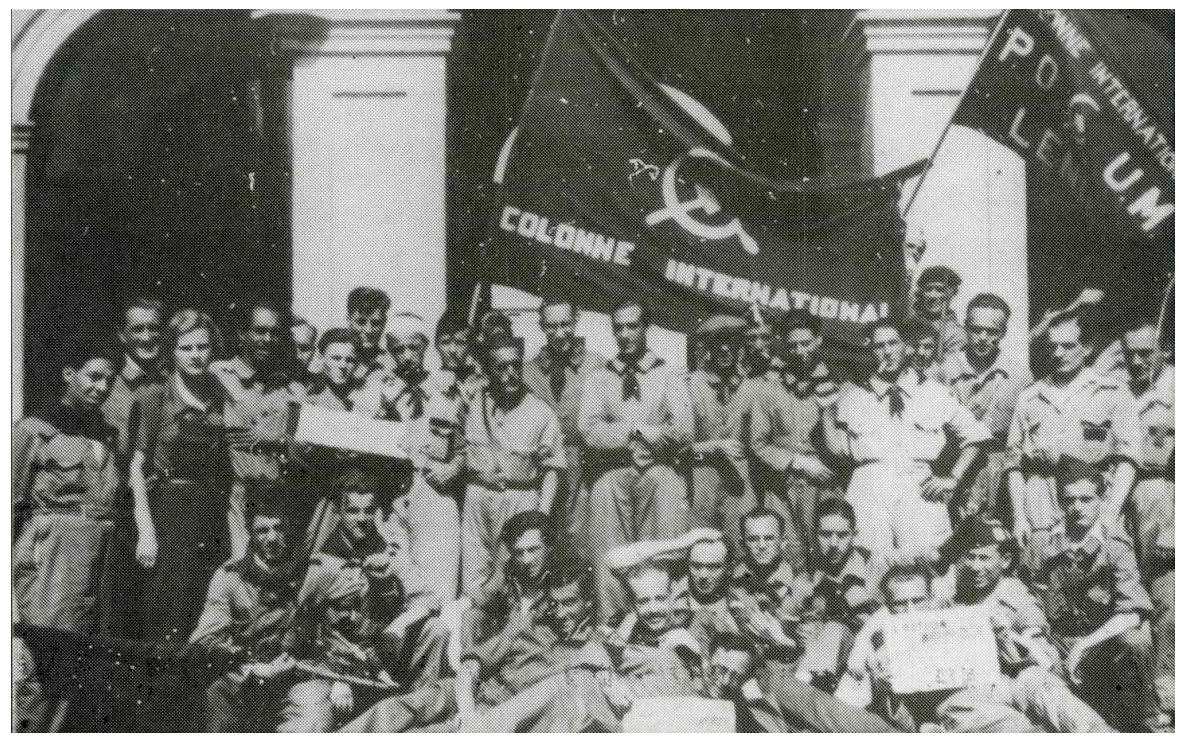

International Lenin Group, Lenin Barracks, Barcelona, August 1936.

(PSMI), which was aligned with the IBRSU, and a group of Trotskyists who would also enter into contact with the POUM. Along with many other anti fascist refugees, these first combatants had taken part in the street fighting on 19 July in the Catalan capital, during which a group led by the Italian Trotskyist Virginia Gervasini and the Austrian PSMI militant Rosa Winkler had seized the Hotel Falcón in the Rambles which would house many of the foreigners who arrived over coming months to support the POUM.

Upon arriving in Aragon the POUM column divided; some moving towards the village of Sietamo, which was briefly taken by a combined force of CNT, POUM and local militia. ${ }^{6}$ The rest of the Column, having taken Alcubierre and other villages with little or no opposition, arrived in Leciñena on the Zaragoza road on 5 August; from where on $17 \mathrm{Au}$ gust they attacked the village of Perdiguera. Among those who took part in what turned out to be a hapless assault by the ill-equipped and badly organised militia was the talented young British poet John Cornford and several KPD(O) members. Cornford, although a member of the British Communist Party, had joined the POUM militia in Leciñena by chance on 14 August, having accompanied the Austrian journalist Franz Borkenau to the

6. The Italian journalist and PSMI member, Bruno Sereni, who had lived in Catalonia since 1933 working as a door to door salesman, was badly wounded and became the POUM's first foreign casualty; see his memoirs, SERENI,B., Ricordi della Guerra di Espagne (Barga 1972). 
front. Within a month he returned ill to Britain where he organised one of the first groups of British volunteers. He would die fighting with the International Brigades in Lopera, Andalucia on 28 December 1936 . $^{7}$

During the first weeks of the war, hundreds of foreign leftists crossed the border to fight fascism and to take part in the revolution. The workers' organisations sought both to channel this solidarity and to vet volunteers. The Italian Trotskyist Nicola Di Bartolomeo was initially appointed by the POUM to coordinate the party's foreign sympathisers through the United International Antifascist Refugees' Centre, which he had established with Virginia Gervasini.

Although international support for the POUM came principally from parties affiliated to the IBRSU and the $\operatorname{KPD}(0)$, the first specifically international unit would be formed on the initiative of the Trotskyists and the Italian Left Communists, follows of Amadeo Bordiga. ${ }^{8}$ During the first days of the revolution, the international Trotskyist movement and Trotsky himself had sought to re-establish relations with the POUM. ${ }^{9}$ Trotskyist volunteers, principally French and Italian, had been fighting with the POUM since the beginning of the war. The Bordigists' exile group had split over the nature of the war in Spain. A minority argued which that it was a revolutionary war had decided to fight fascism in Spain; the majority rejected such participation on the grounds that it was a war between two capitalist blocs.

Negotiations between representatives of the Bordigists and the Trotskyists and the POUM led to the formation of the Lenin International Group (LIG). After a week's training the LIG left Barcelona on 29 August as part of a an eight-hundred-strong POUM Column. The group was commanded by Enrico Russo ${ }^{10}$ and initially consisted of fifty, mainly

7. STANSKY, P. and ABRAHAMS, W., Journey to the Frontier. Two roads to the Spanish Civil War (Boston 1966) pp311-346; F. Borkenau, The Spanish Cockpit (University of Michigan 1974) p108.

8. Brodiga had been one of the founders of the PCl in 1921; in 1926 he split with his supporters from the party. His political programme centred on a rejection of the concept of «socialism in one country» and any suggestion that there was any difference between liberal democracy and fascism, both were forms of bourgeois dominance. Hence his faction rejected «antifascism» as only strengthening capitalism. In contrast, they defended the founding programme of the Comintern and the need to struggle against all forms of opportunism. By the thirties most of the Faction were in exile in Belgium and France and no longer in contact with Bordiga himself, who, after a period in prison, had withdrawn from all political activity.

9. Trotsky had broken with his former Spanish followers who after joining with the Workers and Peasants Bloc to form the POUM in September 1935 had signed the Popular Front electoral pact in early 1936; for a critical appraisal of Trotsky's relations with the POUM see A. DURGAN «Marxism, War and Revolution: Trotsky and the POUM» Revolutionary History vol. 9, n² (London 2006).

10. Russo was a sergeant in the Italian Army during the First World War and later a leading member of the Bordigist faction in exile. 
French and Italian, volunteers. Other foreign combatants already at the front integrated into the Group, as did a steady stream of new volunteers over the coming weeks. By October, the International Group (or «Column» as it was also referred to), forming part of the POUM's $2^{\text {nd }}$ Column, had at least 150 members.

By September there were around three thousand combatants in the POUM's columns, mostly concentrated to the east of Huesca; the rest being based in Leciñena and Alcubierre. The arrival of the International Group at the front on 30 August coincided with the first really serious fighting involving the POUM militia. It immediately joined four hundred combatants, mostly members of the party's youth wing, the Juventud Comunista Ibérica $(\mathrm{JCl})$, which had occupied a wedge of territory centred on the villages of Tierz and Quicena, thus isolating the fascist positions on the Estrecho Quinto ridge and Monte Aragón to the east of Huesca.

Led by cadre of the $\mathrm{JCl}$ with experience of street fighting, the militia forces resisted over the next four weeks attacks by far stronger forces from Huesca. The presence of the International Group, which included a small number of volunteers with experience from the First World War and paramilitary action in Germany and Italy, reinforced the militia's morale and capacity to resist. The young French Trotskyist Robert De Fauconnet became the POUM's first international martyr when he was killed in fighting to cut the Barbastro road on 6 September. In the following weeks the POUM militia, now reinforced, suffered dozens more casualties, including members of the international contingent. ${ }^{11}$

With the abandonment of Estrecho Quinto and Monte Aragón by the fascists on 30 September the militia could now concentrate on besieging Huesca. However, an all-out offensive to take the city was not attempted until 21 October, only to come to a standstill the following day. ${ }^{12}$ The failure of the offensive was later blamed on both the militias' inadequacies and the treachery of their overall commander Colonel José Villalba. ${ }^{13}$

11. The former anarchist militiaman Pedro Torralba praised the courage and efficiency of the POUM militia in defending the «most difficult and dangerous» sectors of the front, TORRALBA, P., De Ayerbe a la Roja y Negra (Edición del autor, 1980) pp146-7; Alba described Casestas de Quicena, where the International Group was situated, as the «most dangerous part of the front», ALBA op. cit. p369; the commander of the attacking fascists Coronel Alfonso Beorlegui described the morale of the defenders of Casetas de Quicena as «extremely high», ARCARAZO, L.A., BARRACHIN, P. and MARTINEZ, F., Guerra civil Aragón. Huecas 'el cerco'Zaragoza 2007 p151; the POUM would later claim they suffered six hundred casualties at the front during September 1936, Front (Terrassa) 28.5.37.

12. Among the international volunteers killed was the nineteen-year-old Franz Maizan , former member of the Austrian socialist militia the Schutzbund.

13. Villalba was commander of the barracks in Barbastro; it is unclear to what extent he was involved in the military plot, probably the arrival POUM militia on 25 July tipped him in favour of the Republic, MALDONADO, J.M., El frente de Aragón. La guerra civil en Aragón (1936-1938) (Zaragoza 2007) pp83, 106, 132; BENITO, M., Orwell en las tierras de Aragón (Sariñena 2009) pp19-20. 
In the previous weeks valuable time had been wasted, allowing the fascists to establish a strong and well-armed line of defence around Huesca. The front now remained stable and there would be no more attempts to take the city until June the following year.

\section{The volunteers}

Most of the POUM's foreign volunteers arrived between August and November 1936, helped across France and the border by Marcel Pivert's supporters in the French Socialist Party, the Gauche révolutionnaire. During the next ten months probably at least six hundred foreign volunteers passed through the POUM militia's ranks on the Aragón front. $^{14}$

Although those who were politically organised were from organisations sympathetic to the POUM, in the early weeks of the war there were also a handful of foreign Communists and anarchists in its militia. ${ }^{15}$ Others were not motivated by any particular political commitment other than a general «anti-fascism»..$^{16}$ At first it seems to have been fairly easy to change units. Foreign volunteers with the POUM switched to CNT and PSUC units and vice versa. The intention of the Republican government after October 1936 was to concentrate all foreign combatants in the International Brigades. While Communist units integrated into the Brigades more or less immediately, there was reluctance among the CNT and POUM international contingents to put themselves under Stalinist control. On the Aragon front only a minority of anarchist and POUM foreign fighters transferred to the International Brigades.

To date it has been possible to identify 367 volunteers from 27 different countries with the POUM in Aragón at some time between August 1936 and June 1937. Of these 107 were German, 77 Italian, 44 French, 39 British, 16 Belgian, 14 Dutch, 10 Polish, 9 Austrian, 8 American and 7 Swiss. There were also volunteers from Algeria, Argentina, Austral-

14. ALBA, op. cit. p369 says there were 500 by January; the former POUM militiaman Albert Masó believed that there were never more than 400 at any one time, letter to author 20.11.97; another POUM leader Carmel Rosa states there were 300 foreigners with the POUM militia, ROSA, C., Quan Catalunya era revolucionaria (I feia la guerra) (Girona 2008) p339; a German militiaman reported that foreigners made up $10 \%$ of the POUM militia, BUSCHAK, W., «El POUM y el movimiento obrero internacional» n.d.

15. Apart from Cornford, four young French Communists also joined the POUM Column in September 1936, three of whom would be killed in the fighting round Quicena; the Italian anarchists Giuseppe Borgo, Pasquale Fioravanti and Mario Traverso formed part of the Lenin International Group.

16. For example the brothers Gottfried and Rudolf Kahn, German Jewish exiles who joined the POUM by pure chance, see the novelised account of their time in Spain, SIMONS, P.L., Brothers on the run. Fleeing Hitler, Fighting Franco (North Charleston 2013). 
ia, Brazil, Czechoslovakia, Cuba, Denmark, Hungary, Ireland, Lithuania, Morocco, Mexico, Peru, Portugal, Rumania, South Africa and Yugoslavia. ${ }^{17}$

As was also the case with the International Brigades the majority of the POUM's foreign volunteers came from countries with authoritarian or fascist governments. The Germans were the most numerous, probably accounting for over a third of all the POUM's international contingent. ${ }^{18}$ Most had left Germany after the Nazis came to power in 1933; some were already resident in Spain before the Civil War, the rest coming from France once the conflict had started. Some had spent time working clandestinely in Germany, others had been imprisoned in concentration camps. Both the $\operatorname{KPD}(\mathrm{O})$ and the SAPD encouraged its members in exile to go to Spain; especially those with military experience. Most of the Germans who served as officers, political commissars or machine gunners were members of these two parties.

Italians formed the second largest group. The majority had been active in anti fascist activities, many having spent time in prison, before going into exile. These were mainly refugees living in France or Spain. Apart from the Trotskyists and Bordigists in the LIG, who were mostly former members of the $\mathrm{PCl}$, the largest group of organised Italian combatants were from the PSMI.

Given that French combatants made up a third of all International Brigade troops, it is reasonable to suppose there were considerably more French volunteers in the POUM militia's ranks than the forty-two identified. Moreover, both North African and Polish combatants often held French nationality. A further thirty-six volunteers resident in France, probably of Spanish origin, were also in the party's militia. ${ }^{19}$

17. This information is based on multiple sources including: the POUM, IBRSU and Trotskyist press; AUSIN HERVELLA, J.L., "Milicians del poum -segons dades de microfilms de l'ANC» https://docs. google.com/document/d/1Ag5WfxlaP_otX2T9tUiurHf5gyS2AAj5vC5IT_bv3oU/edit?hl=es\&pli=1; ABEL, W. y HILBERT, E., "Sie werden nicht durchkommen» Deustche an der Seite der Spanischen Republik und der sozialen Revolution (Auflage 2015); Associazione Italiano Combattenti Volontari Antifascista di Spagna (AICVAS), La Spagna nel nostro cuore 1936-1939. Tre anni di storia da non dimenticare Roma 1996 http://www.aicvas.org/006-Memorie.htm\#cuore; Nederlandse vrijwilligers in de Spaanse Burgeroorlog https://spanjestrijders.nl/user; HALL, C., In Spain with Orwell. George Orwell and the Independent Labour Party Volunteers in the Spanish Civil War (Perth 2013); Le Maitron. Dictionnaire biographique du mouvement ouvrier français (1964-1997); additional information has been located in the CDHM (Salamanca) and the International Brigades' Archive (RGASPI).

18. Orwell says there were «several hundred Germans serving with the POUM», ORWELL, G., Orwell in Spain (London 2001) p67.

19. AUSIN HERVILLA, J.L., op. cit.; apart from members of the Gauche revolutionnaire, the French volunteers included militants from the two Trotskyist parties, the Parti ouvrier internationaliste and the dissident Parti Communiste Internationaliste. 

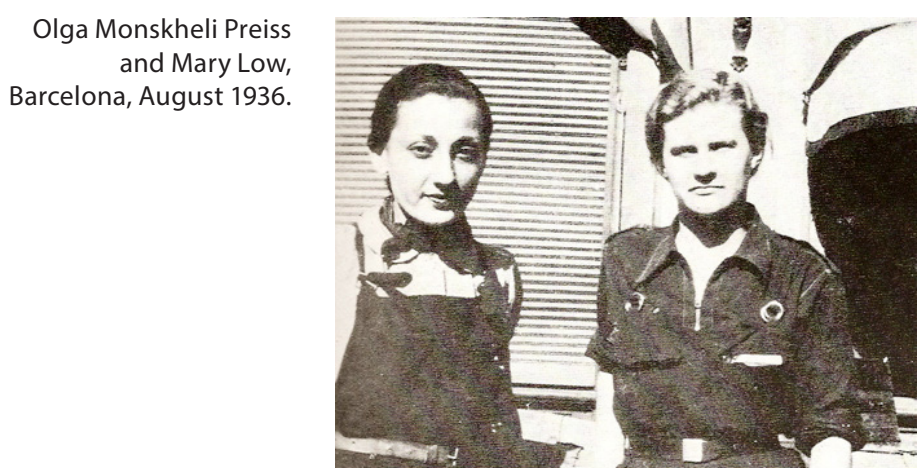

There were few British volunteers before the arrival of the Independent Labour Party contingent in January 1937. Most of the Belgian volunteers were members of the Trotskyist Parti Socialiste Révolutionnaire; several of whom had previously fought in the defence of Irun. ${ }^{20}$ Nearly all of the Dutch volunteers appear to have been members of the IBRSU affiliated Revolutionary Socialist Workers' Party (RSAP), which had been founded by left socialists and Trotskyists in 1935.

Like the International Brigades, many of the POUM volunteers were of Jewish origin; this was particularly the case among the German, Polish and Belgian volunteers and in the militia's medical services. Also like the Brigades, most of the POUM's foreign contingent were in their late twenties and of working class origin. Given that the militias were less strict about the age of volunteers there were quite a few who were under twenty or over forty. The latter included the few volunteers with military experience and, in the case of the Germans and Italians in particular, veterans of the revolutionary movements of the early twenties.

Apart from Orwell and Cornford, other writers and artists with the POUM militia were the Polish writer Wladamir Malacki ${ }^{21}$, better known as Jean Malaquais, the surrealist poets Benjamin Péret ${ }^{22}$ and the Cuban Juan Brea, the German artists Karl Heidenreich ${ }^{23}$

20. DE BEULE, N., «Met de loupe op zoek naar de Belgische Trotskisten in de Spaanse arena« (1987) http://www.journalbelgianhistory.be/en/system/files/article_pdf/BTNG-RBHC,\%2018,\%20 1987,\%201-2,\%20pp\%20399-417.pdf

21. Often described as the «French Orwell», Malacki had emigrated to France in 1925. His first, and highly acclaimed, novel Les Javanais was based on his experiences as a miner; written in 1935 it was not published until 1939, when it won the Renaudot prize.

22. Peret had been one of the founders of the surrealist movement in France and had later become a Trotskyist.

23. Heindereich had been delegate to the Munich Workers' and Soldiers' Council in 1918. With the Nazi rise to power, three hundred of his paintings were destroyed as «degenerate art». 
and Otto Töwe, the British dancer and writer Greville Teixidor and the Italian playwright Mario Traverso.

Probably the most important contribution to the militias of the POUM's international volunteers was as officers and in the medical services. Most foreign officers led international units, as was the case with Enrico Russo and the Frenchman Jean-Claude Lafargue who commanded the Lenin International Group or Bob Edwards of the ILP. Others played an important role in the POUM command structure as a whole, as was the case, in particular, of the Italian Camillo Lanzillota, the German Hans Reiter and the Russian-born Georges Kopp.

As a student Lanzilotta had participated in the struggle against fascist squads in Bari, Pisa and Rome, being wounded twice. In 1922 he joined the Italian army, where he was active in clandestine anti fascist activity until his arrest in 1934. After escaping from prison in August 1936 he made his way, via France, to Spain where he enlisted in the POUM's International Column. His military experience led him to be appointed Chief of Staff of the party's Lenin Division.

Reiter came from a military family and had been a student at the Munich Cadets' School. He would claim in Spain that he had been imprisoned in a concentration camp and his father had been murdered by the Nazis. ${ }^{24}$ What seems clear is that Reiter spent some time in the Foreign Legion before going to Spain in 1935. In charge of a machine gun squad he took part in fighting round Quicena in September 1936 and later commanded the POUM's Shock Battalion.

Kopp presented himself as a Belgian engineer and inventor, a socialist and reserve army officer. He supposedly arrived at the front on the run from his country, having been sentenced to fifteen years in prison in his absence for «making explosives for a foreign power». ${ }^{25}$ However, recent research has shown Kopp's account of who he was to be partially untrue. Kopp did indeed work as an engineer, but had never finished his studies, so was not formally qualified as such. There is no evidence that he was neither in the army nor involved in smuggling military aid to Spain. In reality Kopp had a somewhat turbulent past. He had been born in Saint Petersburg to Belgian parents in 1902, and although he had lived in Belgium since he was seven years old, never took out Belgian nationality. He had aspirations as an inventor and was involved in a number of unsuccessful schemes. The most likely reasons for his leaving Belgium were family problems and debt. Kopp arrived in Barcelona in autum 1936 and convinced the POUM of his anti-fascist and military

24. Reiter's biographical details are contradictory; in the POUM press Reiter always claimed to be a revolutionary, even a former member of the Spartikusbund, Adelante 25.3.37; 2.4.37; Impuls 2.4.37; Front (Terrassa) 6.5.37.

25. This account of Kopp's life can be found, for instance, in Orwell op.cit p151; MORROW, F., Revolution and Counter-Revolution in Spain (New York 1974) p193; in an interview with him in Combat 11.11.36; 4.12.36; or in the ILP's paper New Leader 13.8.37. 


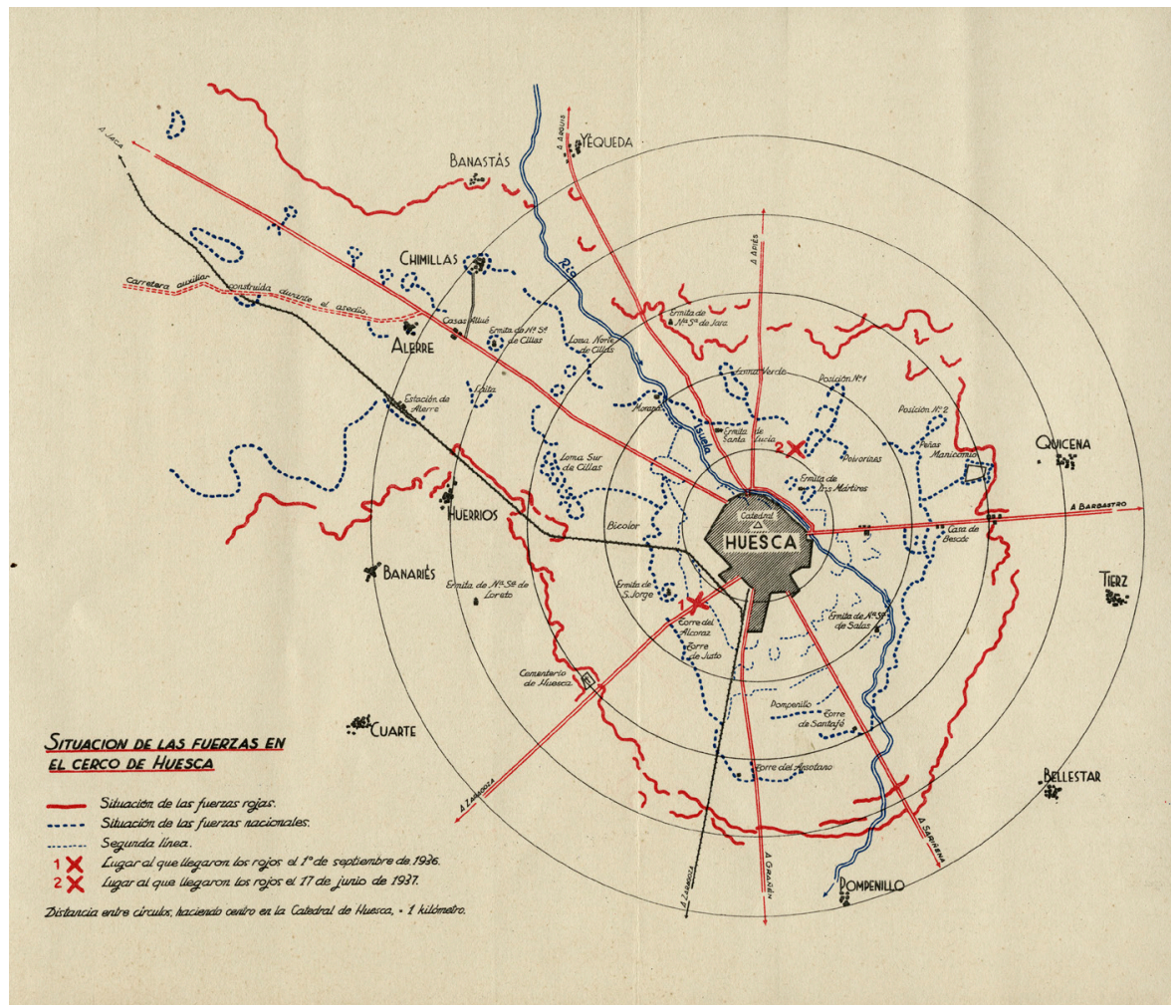

Huesca front, October 1936 - June 1937

credentials and subsequently commanded different units on the Huesca front. Despite his deception, he proved, according to various testimonies, a brave and efficient officer. Kopp would later command the Lenin Division's Third Regiment. ${ }^{26}$

Other foreign volunteers that served as officers in the POUM militia were the Germans Kurz Alvarez ${ }^{27}$, Peter Blachstein, Josep Halm, Erich Hartmut ${ }^{28}$, Peter Huber and Hans

26. GOVAERTS, B., «George Kopp: De vreemde voetnoot in een beroemd leven» Vrij Nederland 24.8.85; B. Govaerts, «Comandante Georges Kopp (1902-1951). De Belgische vriend van George Orwel» (2007); WILDEMEERSCH, M., George Orwell's Commander in Spain. The Enigma of Georges Kopp (London 2010).

27. Alvarez organised the POUM militia's first sapper unit.

28. Hartmut was an officer with the POUM's artillery. 
Sitting, the Italians Enrico Crespi and Paolo Girelli ${ }^{29}$, the Argentine Juan Moner ${ }^{30}$, the Pole Benjamin Lewinski ${ }^{31}$ and the Yugoslav Franjo Čagalj.

Prominent among the POUM's Political Commissars, were the Rumanian Sebastian Wisner and the German Walter Schwarz. ${ }^{32}$ Wisner, probably a member of Rumanian Unified Socialist Party, served on the militia's General Staff. Schwarz liaised between the German contingent and the POUM leadership. Other foreign Commissars included the Germans Otto Breismann and Horst Lichenstein and the Italians Giuseppe Borgo and Amos Salvadori.

Foreign volunteers who played a central role in the militia's medical services. Among the doctors at the front were the Americans Max Gerchik and Louis Levin, the Austrian Sam Salzmann, the German Charlotte Margolin, the Italian Berardino Fienga, the Peruvian José Briones, the Pole Olga Monskheli Preissand the Rumanians Felix Ippen and Salomán Wisner.

Gerchik, a medical student, had come to Barcelona to participate in the Popular Olympics. Levin served as doctor with the ILP Contingent. Margolin, a member of the $\mathrm{KPD}(\mathrm{O})$, who had previously worked at the prestigious Berlin Medical University, had arrived in Barcelona in 1934..$^{33}$ After a period at the front with the Miguel Pedrola Column, she worked at the Maurin Sanatorium in Barcelona. Fienga, a sympathiser of the Bordigists, had gone to the Madrid front with the JSU's October Battalion in July 1936 where he was wounded. He later went to Barcelona where he organised the Lenin Division's medical services. ${ }^{34}$ Briones had worked as a doctor in the village of Oliana, Lleida, before going to the front with the POUM's first Column ${ }^{35}$. Monskheli Preiss had arrived in Barcelona in August, before going to the front with Margolin on 15 September, where she also

29. Girelli, a bricklayer from Brescia, went to Madrid with the $2^{\text {nd }}$ Battalion of the Joaquin Maurin Column in October 1936 in command of the pontoon unit.

30. Moner commanded a Centuria in the Joaquin Maurin Column in Tierz.

31. Lewinski was Jewish and had emigrated with his family to Paris in 1925; he was only twenty years old (he claimed he was 24) when he was handed his command by Kopp in November 1936.

32. Schwarz, a KPD(O) member, had gone to Barcelona in 1932 and was secretary of the POUM in the neighbourhood of Gràcia.

33. Margolin was author in 1923 of an influential study, based on her Doctoral Thesis, on the behavior of the nervous system of carcinoma patients.

34. After the Civil War, Fienga went to Mexico where he became the personal physician of both President Lazaro Cardenas and Leon Trotsky.

35. According to Avant! 25.7.36. the POUM's first Column was equipped with a medical service of two ambulances, two doctors, four medical orderlies three nurses and six stretcher bearers; direct testimonies considered the POUM's medical services to be very precarious: ORWELL op.cit p282; GROSSI, M., Cartas de Grossi (Sariñena 2009) pp57-8; LAUFER, E., «A German Communist in the Spanish Civil War» What Next? No.13, 1999. 


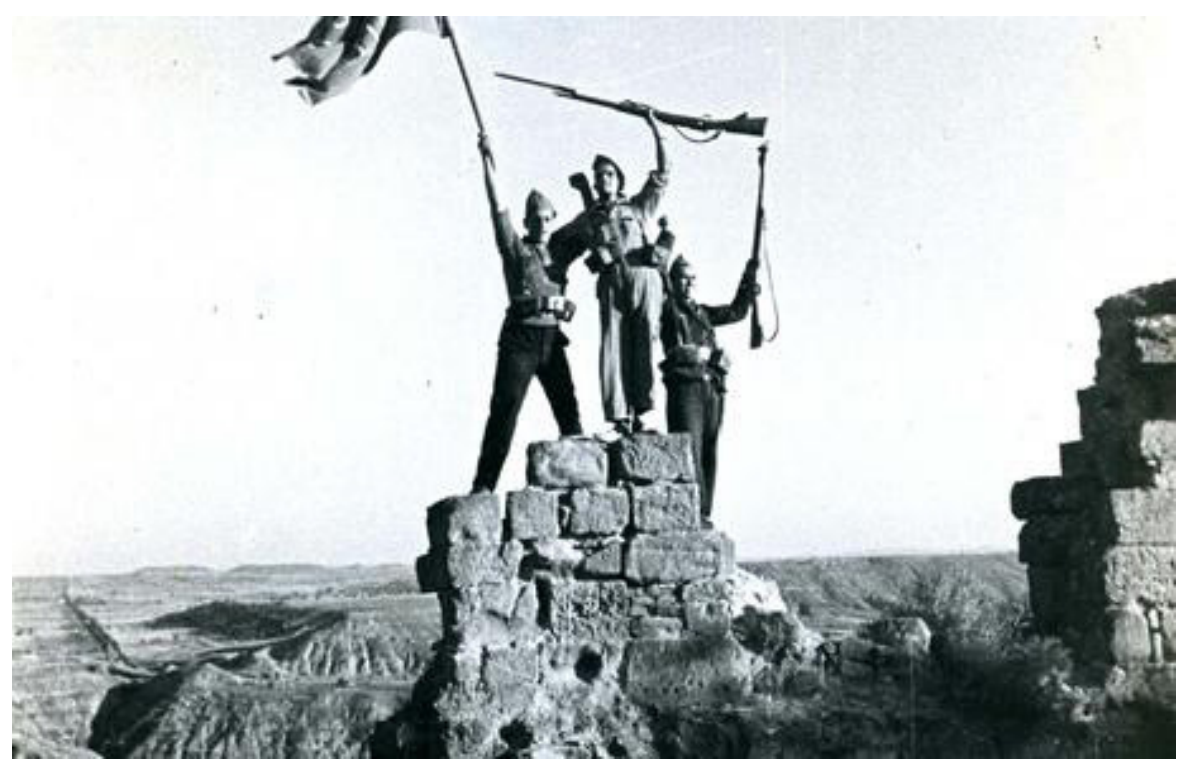

Margarete Zimbal, Montearagon, October 1936

served in the Pedrola Column. Salomán Wisner (Mina), brother of the Commissar Sebastian Wisner, had participated in the Hungarian revolution in 1919 and the Bulgarian Communist uprising in 1923. A specialist in head injuries, and work related injuries he had arrived in Barcelona in May 1936 and helped organise the POUM's first medical services at the front.

Despite the POUM's defence of the incorporation of women in the revolutionary process and the need for their political organisation, few party militiawomen seem to have fought. Most women who were at the front with the POUM, as with other militias, were in the medical services or cooked.

There were various foreign women at the front with the POUM at some stage, including, apart from Margolin and Monskheli, the Austrian Rosa Winkler; the Britons Greville Teixidor (Foster) and Sybil Windgate, the French woman Susagna Lemaitre, the Germans Angelina Franziska, Else Homberger (Henschke) and Eva Laufer and the Italian Giuseppa Buisan. Other foreign women militants played an active role in the rearguard, such as Virginia Gervasini or the British-born Mary Low. Most appear to have been connected to the militia's medical services. Franziska, Laufer, Windgate, Zimbal and, probably, Lemaitre were nurses. Windgate, a member of the Socialist League, was only briefly at the front with the ILP Contingent before the party's representative in Barcelona, John McNair, forced her to return to the rear. Laufer, a medical student, later worked as an orthopaedist in Lleida hospital. Lemaitre was attached to the POUM Artillery. 
Whether the other women fought is unknown. Certainly on the Aragón front there was no equivalent of the Argentine Mika Etchebéhère who led a POUM Company on the Madrid front. Rosa Winkler went to the front with the LIG, but had returned to Barcelona by October. The writer and dancer Teixidor was briefly with the POUM at the beginning of the war before joining the Durruti Column. The Swiss Trotskyist Clara Thalmann spent a short time with the POUM Shock Battalion in April 1937 after having been with the Durruti Column. ${ }^{36}$

One exception was the nineteen-year-old German Magarete Zimbal who before the war had fled her Nazi father, travelling to Spain in 1933, where she met Erwin Bresler. They lived by busking and in 1936 arrived in Sitges, where they joined the $\mathrm{JCl}$ and lived with $\mathrm{KPD}(\mathrm{O})$ members Else Homberger and Gerhard Henschke. In August 1936 all four went as part of the POUM contingent in the campaign to retake Mallorca where Bresler was killed. Upon returning to Barcelona, Zimbal went to the Aragon front. She was killed on 22 October during the offensive on Huesca.

At the time of her death, Zimbal was described as a nurse, but she had also fought. She became a martyr for the $\mathrm{JCl}$ and her funeral in Barcelona was accompanied by a large demonstration of all the workers' organisations. In her honour it was decided to form a solely women's battalion, the Magarita Zimbal Battalion, but this never materialised, despite the POUM being the only workers' organisation to offer women military training in the rearguard. ${ }^{37}$

\section{The Lenin Division}

As the war progressed it was clear on the Republican side there was an urgent need to organise the war effort on a more centralised and efficient basis. Parallel to the rebuilding of the Republican state was the organisation in October 1936 of the new Popular Army. The POUM also insisted, contrary to what is often asserted, on the creation of unified command and a disciplined army. Rather than the «bourgeois» Popular Army, such an army would be modelled on the Soviet Red Army during the years of the Russian

36. Thalmann had gone to Spain, where she was joined by her partner Pavel Thalmann, as part of the Swiss Workers' Swimming Club to take part in the Popular Olympics.

37. According to the POUM, Zimbal «fought like a man, she aimed her rifle and fired without rest, impassive to the fascist bullets... she constantly exposed herself in order to rescue the wounded... She was the prototype of the revolutionary woman... feminine but strong, brave, heroic...» Front (Sitges) 25.10.36; La Vanguardia 23.10.36; Spanish Revolution 2.12.36; also see CASTELLVÍ, O., De les txeques de Barcelona a l'Alemanya nazi (Barcelona 2003) p41-43; according to the POUM daily La Batalla about 100 women regularly took part in these training sessions, $L a$ Batalla 8.1.37. 


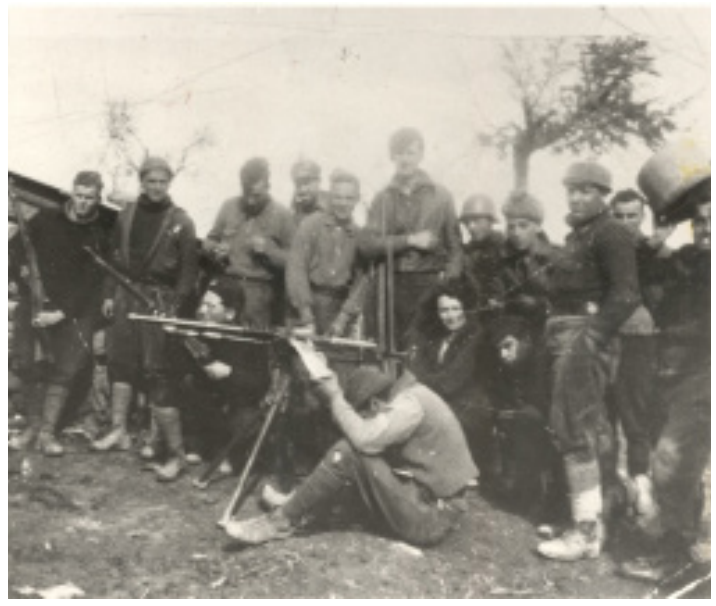

George Orwell, Eileen O'Shaughnessy and members of the ILP Contingent

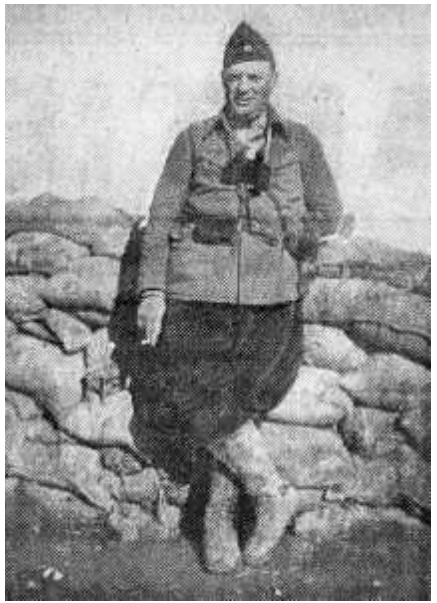

Georges Kopp

Civil War. It would be under control of the workers' organisations, albeit not organised along party or union lines as were the militias. All workers between the ages of 18 and 30 would be recruited to fight. As a measure of «revolutionary hygiene» bourgeois and middle class elements would only carry out logistical tasks such as digging trenches. ${ }^{38}$

In Catalonia, the militias had been under the control of the Anti Fascist Militia Committee and, after early October, by the newly unified Catalan Government. With the introduction of militarisation, the Catalan militias were transformed into the Catalan Popular Army in December 1936 controlled by the Generalitat's Defence Council (Ministry), rather than by the Republican Government in Valencia. The Catalan Army was divided into Divisions, each with three Regiments made up of four Battalions of 440 men, with their own artillery, machine gun, communications and sapper units. ${ }^{39}$

38. For example according to José $M^{a}$ Maldonado the POUM «fled from traditional discipline and obeying either military or civilian commanders « MALDONADO op.cit p38. On the POUM military policy see TOSSTORFF, R., El POUM en la revoució espanyola (Barcelona 2009) pp155-171; and the report from the POUM's Military Conference in, Lerida, 17-19 January 1937, La Batalla 23.1.37; 24.1.37.

39. By early 1937 there were supposedly 42,466 men in the Republican forces on the Aragón front, with 132 pieces of artillery; the rebel $5^{\text {th }}$ Division in April 1937 had 42,873 troops, 6,182 in the Huesca sector, and 131 pieces of artillery, MALDONADO op. cit. pp143-145. 
La Loma del Manicomio

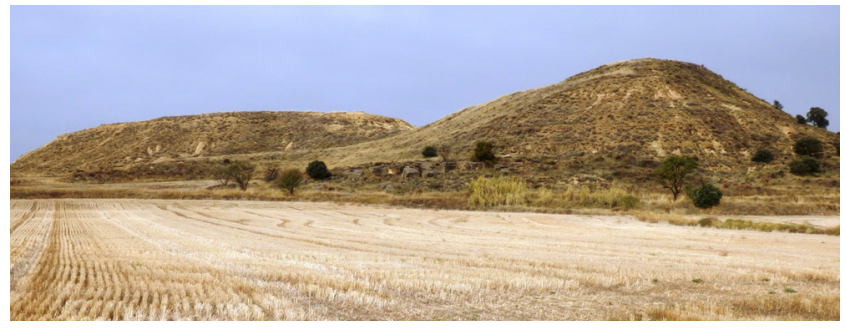

Even before the setting up of the Catalan Army, the POUM's militia had undergone its own version of «militarisation» under Josep Rovira ${ }^{40}$, who had been appointed commander of the party's forces on 19 September. Rovira introduced more efficient training, better defences and military re-organisation. Previously, like other militia, the POUM's forces had been organised into Centurias or Banderas of around one hundred combatants. Battalions were formed on the basis on four Centurias, which in turn became companies.

In contrast to the view popularised by Orwell, memoirs and reports of the time present the POUM militia as well organised and disciplined, despite the adverse circumstances. Discipline was maintained principally on the basis of the political commitment of the combatants; desertions were very rare, despite the lack of leave. ${ }^{41}$ Likewise positions were more efficiently defended than the impression given by Orwell. A report written by the veteran $\mathrm{KPD}(\mathrm{O})$ militant, Waldemar Bolze, in April 1937 describes the impressive state of the defence networks in the Tierz-Quicena sector, where trenches in some places were barely fifty metres from the enemy. ${ }^{42}$

By late December 1936, the POUM militia was organised into four columns: the Miguel Pedrola Column, formerly the Second, the Joaquin Maurin Column and the small-

40. Rovira was previously head of the POUM's paramilitary self-defence groups

41. ORWELL, op.cit pp318-320; according the Josep Pané, Political Commissar in the POUM militia, the large presence of party members, around $80 \%$ at first, reinforced discipline, COLL, J. and PANÉ, J., Josep Rovira. Una vida al servei de Catalunya i del socialismo (Barcelona 1978) p114; the POUM press from very early on was full of calls to improve discipline, for example «Instrucciones que se han dado a sí mismas las milicias del POUM en campaña» La Batalla 8.8.36.

42. "Three months on the Huesca Front», The Spanish Civil War. The view from the Left, Revolutionary History Vol.4, Nos. 1/2, (London 1992); Josep Guarner, Chief of Staff of the Army of Catalonia, when questioned at the POUM leadership's trial in November 1938, stated he was unaware of any complaints about the fortifications in the positions occupied by the party's militia, El proceso del P.O.U.M. Documentos Judiciales y Policiales (Barcelona 1989) p411; Orwell admitted that the lines were often close in front of Huesca, ORWELL op. cit. p281; Front (Terrassa) 24.12.36. described the lines as being only fifty metres apart in front of the Manicomio. 
er Miguel Lobo and Juventud Comunista Ibérica Columns. These Columns occupied a fifteen kilometre stretch of the Huesca front that ran from La Granja (to the east of Montflorite) in the south to near Fornillos de Apiés in the north. While the larger Pedrola and Maurín Columns held the section to the north of the hamlet of Bellestar, the Lobo and JCI Columns were stationed around Montflorite and in the Sierra de Alcubierre to the south. From late November, the POUM columns already referred to themselves as the «Lenin Division» but the formal reorganisation of the Columns as part of the Catalan Popular Army into Regiments, with Battalions and Companies was not complete until late March $1937 .{ }^{43}$ By then the Lenin Division was supposedly composed of 6,590 troops: 5,750 infantry, 196 artillerymen (two batteries), 264 cavalry and 380 sappers (two companies). ${ }^{44}$

All the militia forces on the Aragón front complained of the lack of arms. There were constant calls for arms to be sent to the front and for an immediate offensive to be launched. In particular, the lack of artillery and air cover made the taking of (after early October 1936) well-defended enemy positions near impossible. ${ }^{45}$ Increasingly the Republican Government was accused of sabotaging the Aragon front because it was dominated by the revolutionary left.

The Lenin Division lack of sufficient arms and material meant that it was never formally recognised by the Catalan Government. For 5,750 infantry the Lenin Division had 3,752 rifles (65\%) compared to the Ascaso Division, with whom it shared the Huesca front, which had 5,495 rifles for 7,090 infantry (77\%). A bigger problem was the lack of machine guns - so essential for trench warfare. The Lenin Division had only twenty-five compared to the Ascaso Division's ninety-four. ${ }^{46}$

The figures on their own do not take into account the quality of arms available. Testimonies agree on the poor quality of both rifles and machine guns and the lack of ammunition, which even if this was available was often of different calibres. Artillery fire,

43. Until late March the old denominations were still used; then the Maurin Column became the $1^{\text {st }}$ Regiment, the Pedrola Column the $2^{\text {nd }}$ and the $\mathrm{JCl}$ and Lobo the $3^{\text {rd }}$; for the distribution of the POUM forces see: Cuartel General del Frente de Aragón. Estado Mayor, 3a Sección Sariñena, marzo 1937, «Operaciones. Plán de operaciones sobre Huesca» AHM Caja 786,2.

44. «Líneas generales de la organización de las fuerzas que guarnecen la región catalana» Documento 0297, Fundación Anselmo Lorenzo; a fascist report in March 1937 claimed the Lenin Division consisted of 7,300 men, with 80 machine guns, and eighteen pieces of artillery, $5^{\text {a }} \mathrm{Di}$ visión Orgánica EM «Parte informativa correspondiente del día 22 de marzo de 1937» AHM Caja 2417,11.

45. José Ma Maldonado estimates, given the lack of both men and suitable arms and the strength of the enemy's defences, it was «nearly impossible» for the Republican forces on the Aragon front to take the enemy's positions, MALDONADO op.cit. p94; Waldemar Bozle makes a similar point in «Three months...» op.cit. pp294-5;

46. "Líneas generales de la organización de las fuerzas que guarnecen la región catalana» Doc 0297, Fundación Anselmo Lorenzo ; MALDONADO op.cit. pp511-513. 
due to lack of shells and the poor state of the cannons, was sporadic and generally inaccurate. The arms available only began to improve slightly when the Catalan Army was integrated into the Popular Army in May 1937.

The Army of Catalonia now became the Army of the East under the control of the General Staff of the Popular Army. Each Division was with numbered and re-organised into three Mixed Brigades, each consisting of four Battalions with its attendant sections, totalling, in theory, 4,269 men. However, on the Aragón front no Mixed Brigade was ever complete and when the front fell in March 1938 few had more than two and half thousand troops, about the same size as the Regiments they replaced a year before. ${ }^{47}$ The Lenin Division was now formally recognised, becoming the $29^{\text {th }}$ Division; albeit it only had sufficient men and material for two Brigades, the $128^{\text {th }}$ and the $129^{\text {th }} .{ }^{48}$

\section{Orwell and the ILP Contingent}

On 12 January, twenty-five volunteers organised by the ILP arrived in Barcelona. The ILP had broken with the Labour Party in 1932 over its support for the National Government and had evolved towards revolutionary socialism, becoming one the principal organisers of the IBRSU. It had begun to organise recruitment for Spain in November after one of its leaders Bob Edwards had travelled to Barcelona with an ambulance donated to the POUM. This first group was presented as the vanguard of a larger force to follow, but the British Government's ban on its citizens fighting in foreign armies stopped further recruitment. ${ }^{49}$ They were joined at the front by other English-speaking volunteers including Orwell, who had arrived at the front with a Centuria of the new JCl Column three weeks beforehand.

Over the next five months at least forty-five volunteers, including medical personnel, passed through the ILP Contigent's ranks. Of these, thirty-five were British citizens, four were Americans, three Irish, one Australian, one Polish and one South African. The British citizens included at least six Scots, five Welsh and two from Northern Ireland. Twenty-four of them are known to have been members of the ILP. Three were members of the Socialist League, a faction inside the Labour Party. The Pole Juliusz Kampfer was a member of the Polish Independent Socialist Party; the American Harry Milton of the Revolutionary Workers' League and the eighteen-year-old Stafford Cottman of the Young

47. MALDONADO, op.cit. pp169-170; 516-518; Vicenç Guarner stated he never saw a Mixed Brigade that was complete at the front, GUARNER, V., Cataluña en la guerra de España (Madrid 1975) p.225.

48. The $1^{\text {st }}$ and $3^{\text {rd }}$ Regiments combined to form the $128^{\text {th }}$ Mixed Brigade and the $2^{\text {nd }}$ Regiment became the $129^{\text {th }}$.

49. The ILP representative in Barcelona, John McNair claimed there were two hundred inscribed to come, La Batalla 1.4.37. 
Communist League. ${ }^{50}$ According to the MI5 fifteen of the ILP Contingent had military experience before going to Spain. ${ }^{51}$

Orwell had gone to the front with young inexperienced militia; part of the recently formed $\mathrm{JCl}$ Column which was sent to the Alcubierre mountains. There they joined the remnants of the probably demoralised forces that had been overrun in Leciñena the previous October. Orwell was «profoundly disgusted» when he found that the enemy was some seven hundred metres away. He seems unaware that other militia, principally from the PSUC's Carlos Marx Division, were very close to the fascists' isolated «San Simon» position in front of him which had been taken after the fall of Leciñena. In late February, the POUM forces in the Alcubierre area were sent some sixty kilometres north to join their comrades facing Huesca. The ILP Contingent was transferred to the lines in front of La Granja, as part of the newly organised Third Regiment under the command of Georges Kopp. Although Orwell commented on the improvement in the condition of the defences, as well as in arms and training, he was still in what was the quietest part of a by now quiet front.

\section{The Shock Battalion}

With the reorganisation of the POUM militias, the foreign volunteers were also reorganised. In October the Lenin International Group had suffered a crisis when twenty-nine of its members, mainly Bordigists and Trotskyists, resigned in protest at the POUM's acceptance of militarisation. ${ }^{52}$ The Bordigists now claimed the war had ceased to be revolutionary and most left for France or went to work in the rearguard; albeit Enrico Russo, the Group's commander, remained on the POUM Militia's General Staff until at least January $1937 .^{53}$ Having become increasingly critical of the POUM, especially since its decision to

50. Most of this information can be found in HALL op. cit; in May 1937 Orwell was in charge of thirty «English and Spanish» militia, ORWELL op.cit p50.

51. LARGEAUD, B., La perception des volontaires britanniques de la guerre 'Espagne, de la surveillance à la redécouverte Université Paris Sorbonne - Paris IV, UFR d'Histoire, September 2013 p114

52. Bilan 22.10.36.; for a detailed account of the crisis see GUILLAMON, A., Documentación histörica del trotquismo español (1936-1948) (Madrid 1996); ROSES, S., Els revoulucionaris marxistes a I'Espanya del anys 30, Tesi Doctoral, Facultat de Geografia i Historia Contemporànea, Universitat de Barcelona, Maig de 2017, pp305-354.

53. Russo signed on 28.1.37. for the receipt of his wages from 1.12.36. to 15.1.37; ANC 1-1-T6489/824; at least two other Bordigsts kept fighting: Emilio Lionello; re-enlisted in the POUM militia in the Miguel Pedrola Column, and returned to the front on 16.11.36., he signed on 7.1.37. for his wages for the period 16.11.36. to 31.11.36 ANC 1-1-T-6436/421-422; Gildo Belfiore later joined the International Brigades, Associazione Italiano Combattenti Volontari Antifascista di Spagna (AICVAS) La Spagna nel nostro cuore 1936-1939. Tre anni di storia da non dimenticare Roma 1996 http://www.aicvas.org/006-Memorie.htm\#cuore 
join the Catalan Government in late September 1936, some of the Trotskyists now went to fight in CNT units. Others, like the members of the dissident Parti Communiste Internationaliste or the Dutch remained inside the POUM militia. A consequence of the growing tension between the POUM and the Trotskyists was the replacement of Di Bartolmeo with the Austrian dissident communist Kurt Landau as coordinator of the POUM's international department. Max Diamant, who arrived in Barcelona in October to represent the SAPD, consolidated the hold of IBRSU affiliates over the POUM's international apparatus.

Meanwhile a renewed attempt on 21 November to take the Loma del Manicomio in the Quicena sector led Rovira to see the need to organise a Shock Battalion based on volunteers who had some military experience. Two thirds of the new «Rovira Shock Battalion» were foreign volunteers; many of the rest being former members of the Bandera Pedrola that had showed their worth during the fighting round the Barbastro road in September. Most of the, by now numerous, German contingent were drafted into the Shock Battalion, as were the majority of Dutch and Central European volunteers and a smattering of other nationalities. The militia's General Staff were convinced of the German combatants' military prowess and they were initially prominent among its officers and commissars. The $\operatorname{KPD}(\mathrm{O})$ member Peter Huber was its first commander. Reiter was initially second in command.

In theory the new Battalion's troops had to be members of the POUM or one of the IBRSU affiliated parties and be prepared to «struggle till death». ${ }^{54}$ The Battalion was provided with the best arms and its own dark green uniforms. ${ }^{55}$ Discipline and training was strict and anyone refusing to obey an order "would probably be shot». At its base in Fañanás, about twelve kilometres behind the lines, the Battalion set up its own gymnasium, library and school, which, among other things, taught languages. ${ }^{56}$ With the forming of the Shock Battalion, a separate International Column (or Group) ceased to exist. Those foreign volunteers not in the new Battalion were integrated into different Centurias or specific sections, as was the case with the Gauche révolutionnaire, PSMI and ILP.

The little fighting POUM troops participated in prior to the offensive in June 1937 involved the Shock Battalion. ${ }^{57}$ It first saw action on 6 January when Republican forces

54. A fascist report described the Battalion being made up of militiamen who were «well trained and well armed specially chosen fanatics» «Informe sobre el ataque del día 17 del actual posición número dos» 21.3.37. AHM 1299,53.

55. These were made in a workshop in Lleida and «provoked a certain admiration and respect» among the rest of the Lenin Division, COLL, op. cit. p119; Grossi described the Battalion as the «the best dressed and most disciplined unit at the front» GROSSI, op.cit. p99.

56. A. FORNER «El Batallón de Choque Rovira» Juventud Comunista 13.5.37; according to Orwell the Germans «did not speak a word of English, Franch or Spanish» ORWELL, op. cit. p83.

57. The Battalion's «heroism» would later be attested to by the CNT militia leader Miguel Garcia Vivancos, «Informe» 21.7.37. FAL; The Dutch volunteer Anton Van de Berg recalled that he was involved in a dozen or so attacks as a member of the Battalion, https://spanjestrijders.nl/bio/ berg-toon-van-de 
retook the villages of Lierta and Arascués, some fifteen kilometres to the north of Huesca, that had been captured by the fascists on 20 December. Apart from the Shock Battalion, troops from two other POUM Centurias took part, as did units from the CNT's Ascaso Division and the Barbastro Militias. Led by Huber and Reiter's machine gun section, the Shock Battalion took the Arascués ridge and then stormed the village of Liertes in a lightening attack, after the CNT militia had secured the flanks. The militia involved were congratulated for their «brilliant» success. At least three young international volunteers lost their lives. ${ }^{58}$

On 19 February fascist troops took the village of Vivel del Rio Martin, eighty kilometres to the north of Teruel. Lacking reserves in the area, an expedition including troops from the Shock Battalion, now under the command of Reiter, and the Maurin and JCl Columns, the PSUC and CNT militias was sent four days later to retake the village. Despite the POUM and CNT troops occupying positions around Vivel, the attack was beaten back. In the following weeks the POUM press blamed the PSUC unit for having remained passive, and thus sabotaging the attack. ${ }^{59}$

The bloodiest action involving the Shock Battalion prior to the June offensive, was a renewed attempt to seize the strategically important ridge known as the Loma del Manicomio on 17 March 1937. Designated by the fascist forces as "Position Number 2», the two hillocks that formed the ridge dominated the surrounding area. The assault was part of an operation designed by the General Staff to take pressure off Guadalajara (the battle had started on 8 March) and to strengthen positions so as to definitively isolate Huesca. ${ }^{60}$

Given the strength of the fascists' defences, the initial assault took place under the cover of darkness. At four in the morning, sixty Shock Battalion troops led by Reiter took the most northerly hillock in a surprise attack after flinging hand bombs into the enemy trenches. In the hand to hand fighting that ensued around forty Civil Guards were later reported to have been killed. Conflicting reports in the POUM press suggest that some of the enemy troops may have been eliminated after having surrendered. Fascist sources, however, only speak of thirteen losses and make no mention of any massacre.

Reinforced, the Shock Battalion troops held the captured position for six hours be-

58. GUARNER, op. cit. p259; the Official Communique of the Republican Army 7.1.37. claimed the militia had captured a cannon, a machine gun, a mortar, twenty rifles, 30 boxes of ammunition and five prisoners, and the enemy had left fifty dead behind, Servicio Histórico Militar, Partes Oficiales de Guerra: 1936-1939 vol. II (Madrid 1978) p.168. Militia the dead included the Germans Adolf Hess (18 years old) and Rudolf Hable (19); and the Swiss Gregor Bobilof (21); La Batalla 13.1.37; Impuls 26.3.37; HUBER, P., Los voluntarios suizos en la guerra civil española Guadalajara 2011) p142.

59. Among the dead was the SAPD member Ewald Linke; La Batalla 26.2.37; 2.3.37; Juventud Comunista 4.3.37; 20.5.37; Alerta 4.3.37.

60. Cuartel General del Fente de Aragon. Estado Mayor, 3a Sección, Sariñena, marzo 1937, «Operaciones. Plán de operaciones sobre Huesca (Marzo 1937)» AHM Caja 786,2. 
fore being forced to retreat as none of the other objectives in the planned Republican operation had been taken, thus allowing the fascists to bring up more troops and use artillery and aerial bombardments to retake the hillock. Enemy infantry had used 12,000 rifle cartridges, ninety grenades and a hundred mortar bombs before taking the position at bayonet point. Promised Republic aerial support failed to materialise. ${ }^{61}$

The withdrawal, across open ground to the POUM trenches proved costly with at least twenty five of the Battalion being killed and another sixty-five wounded. According to fascist sources there were around fifty Republican dead, including five who were taken prisoner and executed. Among the dead were British, Dutch, French, German, Italian, Moroccan and Catalan volunteers. The Battalion's heroism was lauded in the POUM's press and a parade at the funeral of those killed, was addressed, by among others, a German member of the Lenin Division's General Staff, Josef Halm and the Rumanian Political Commissar Sebastian Wisner. ${ }^{62}$

Early morning on 13 April, to relieve pressure on the Ascaso Division attacking to the north, seventy Shock Brigade troops, mostly Germans, were involved in a night time raid on the lines in front of the Ermita Salas to the east of Huesca - an action that is graphically described by Orwell in Homage to Catalonia.

Fifteen members of the ILP Contingent, including Orwell, also took part, along with other troops from the $3^{\text {rd }}$ Regiment's 2 nd Battalion commanded by Gregorio Jorge ("Jorge Roca»). It would be the only action the ILP Contingent participated in and could only be considered a minor success. The Shock Battalion was unable to take the position allotted to it due to heavy enemy fire. A few arms were captured and there were reports of fascist casualties. Most tragically a dozen JCI members remained trapped in no-man's land throughout the following day. Only one made it back alive. ${ }^{63}$

61. The POUM's version of events can be found in: La Batalla 18.3.37; 20.3.37; 29.4.37.; Adelante 19.3.37; 2.4.37; the official Republican version in Partes Oficiales... op.cit vol. II, p248; La Vanguardia 18.3.37; the fascist version in: Ejército del Norte. Quinta División, «Parte del combate librado el día 17 de marzo de 1937 en Huesca» AHM Caja 1315,34.; 5a División Orgánica Estado Mayor, «Parte informativa correspondiente del día 22 de marzo de 1937»AHM 2417,11.; also see ARCARAZO, op.cit. pp238-239.

62 The POUM figures can be found in: La Batalla 20.3.37; 21.3.37; L'Espurna 9.4.37; Frente Proletario (1938); according to the fascists the Battalion was «destroyed» losing at between 60 and 45 combatants, including its commander Reiter, «Parte del combate....» op.cit; «Parte informativa...» 22.3.37. op.cit; «Información sobre el ataque enemigo del 17 de marzo 1937» AHM c1299, Cp53.

63. ORWELL, op. cit. pp76-88; ARCARAZO, op.cit. p272; MALDONADO, p76; COLL, op. cit pp146147; GUARNER, op.cit. p265; Spanish Revolution 21.4.37; Adelante 16.4.37; La Batalla 14.4.37; 24.4.37. 


\section{The $29^{\text {th }}$ Division}

Meanwhile the campaign against the POUM, accused by the Stalinists of being in league with the enemy, continued unabated and formed the backdrop to the fighting that broke out in Barcelona in early May. ${ }^{64}$ Around seventy POUM militiamen, mostly from the Shock Battalion, had already been sent to Barcelona to protect party premises. ${ }^{65}$ They were joined by Orwell and a small group of ILP volunteers, who were on leave. At least nine of this group, including Orwell, had hoped to pass over to the International Brigades as some other POUM foreign volunteers had already done. ${ }^{66}$ What they witnessed in Barcelona would convince most of them that they could not abandon the POUM when it was being slandered and physically attacked.

When news of the fighting reached the front it caused a wave of indignation but, contrary to what has been claimed, POUM troops did not abandon the trenches to go to Barcelona. ${ }^{67}$ Instead, Rovira, with «a strong escort» of Shock Battalion soldiers went to Binefar to investigate. On the way, at Sietamo, «several hundred» soldiers from the CNT's $28^{\text {th }}$ Division joined them. The CNT troops were persuaded to wait in Binefar, where they clashed with local forces. Meanwhile Rovira went with $28^{\text {th }}$ Division commanders Máximo Franco and Miguel García Vivancos to Lleida where they met with Coronel Alfonso Reyes, PSUC member and commander of the sector's air force and Joaquim Vilar, the Catalan Government's Commissar of Public Order in the province. An agreement was reached that the CNT troops would return to the front, while at the same time all govern-

64. For instance, the PCE described the POUM as «the advance line of fascism» in the Republican zone and called for its «extermination», Mundo Obrero 29.1.37; the XIV International Brigade newspaper claimed that after the Moscow trial «the whole world can see» that the Trotskyists were «agents of German-Japanese fascism.... an incredible system of provocations, sabotage and murder» and in Spain, they had been revealed as «the artificial mist that hid Franco's Fifth Column». The «unmasking of the Trotskyists», it claimed, united all International Brigade volunteers, Soldado de la República 16.2.37.

65. ALBA, op.cit p406; according to the NKVD at least thirty-seven foreign POUM militia were sent to take part in the May «putsch», 30.6.37. RGASPI (Thanks to Peter Huber for providing a copy of this information); Reiter was later accused by the KPD of having taken part in May fighting at the head of a «twenty-strong unit of Shock troops»; ABEL op.cit. p406.

66. HOPKINS, J.K., Into the Heart of the Fire. The British in the Spanish Civil War (Stanford 1998) pp205-6; LARGEAUD, op. cit. p112.

67. Most studies use the unsigned document «Informe que envía la asesoría jurídica del frente de Aragon en virtud de la orden telegráfica del General Jefe del Ejercito de este» AHM Caja 577.1.4; this provided the basis for the PCE's version of events, which claim that the CNT and POUM «abandoned» the front: Guerra y revolución en España 1936-1939 vol III, (Moscow 1971) p76; IBARRURI, D., They Shall Not Pass.The Autobiography of La Pasionaria (New York 1976) p286. 
ment forces would be withdrawn from outside the CNT and POUM offices in the province. ${ }^{68}$

In the coming weeks repression against the most radical sectors of the workers' movement increased with widespread arrests ${ }^{69}$ and the closing down of newspapers and offices. The POUM was blamed for having organized the «May putsch». Communist appeals for the «Trotskyists» to be suppressed, if not physically annihilated, became even more strident. To this backdrop an offensive on Huesca was finally organised as part of a broader plan to take pressure off Bilbao. Twenty thousand troops, eight thousand of which, including the XII International Brigade, had been brought up from the Central zone, supported by 18 artillery batteries and 150 planes, were deployed. Rebel forces in and around Huesca numbered some 10,000.

Considered untrustworthy by the Communist commanders of the Ejército del Este, the POUM's $29^{\text {th }}$ Division was initially allotted a secondary role in the offensive. At 04.00 hours on 12 June the $2^{\text {nd }}$ Batallion of the Division's $129^{\text {th }}$ Mixed Brigade launched a diversionary assault on the Manicomio (psychiatric hospital) and the nearby ridge. Given the superior firepower of the entrenched defenders the attack was beaten back, with, according to the fascists, the POUM forces suffering heavy casualties. ${ }^{70}$ With the initial failure of the offensive to cut the road to Jaca and complete the encirclement of Huesca, a new plan of attack was drawn up which included a direct assault on 15 June at 01.00 by the POUM's Shock Battalion on the heavily fortified Loma Verde (Green Ridge) immediately to the north of the city. Aware of the imminence of the attack, the fascists concentrated heavy artillery fire and air strikes on the sector, forcing the Battalion to retreat. ${ }^{11}$

Early the following morning, on the very day the POUM was illegalised in the rearguard and its leaders arrested, two companies from the $129^{\text {th }}$ Mixed Brigade's $4^{\text {th }}$ Battalion took by surprise the fascists' strategically important Number One Position situated on the Loma de las Martires to the east of the Loma Verde. The two Companies were joined by

68. COLL, op.cit, pp163-173; BARULL, J., El Bloc Obrer I Camperol (Lleida 1919-1937) (Lérida 1990) p.112; El proceso... op.cit pp 412, 494-6, 503-4, 511, 519; TORRABLA, op.cit pp115-116; BOZLE «Three months... op.cit p. 289; «El Comité Executiu del POUM dona orders de que no vinguin a Barcelona forces del front» Declaración 6.5.37.(Biblioteca de la Republica, Barcelona); Adelante 7.5.37.

69. Including some of the POUM's international volunteers, among them the Germans Hans Levy, Hans Sittig (KPD[O]), Paul Schmiedel and Ernst Steinhoff (SAPD), Harvey Buttonshaw, Douglas Thompson and David Wickes from the ILP Contingent, and the French Trotskyists Gaston Ladmirall and Élie Rosijansky.

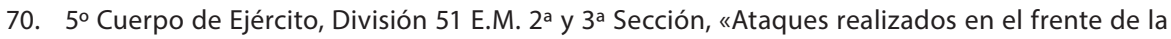
División en los días 12 al 19 de junio» AHM Caja 2100,18.

71. Ejército de Este, Estado Mayor, «Orden General de Operaciones n¹0» 13.6.37. AHM C581. 19/3; ARCARAZO, op.cit p314; ALBA, op.cit p537; FERNÁNDEZ JURADO, R., Memòries d'un militant obrer (Barcelona 1987) pp242-3; COLL, op.cit p178. 


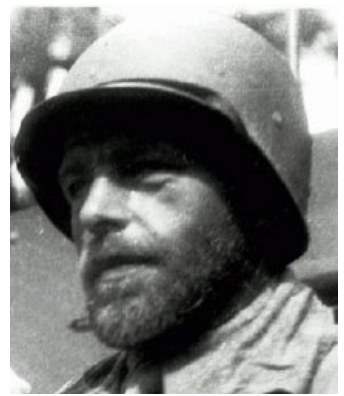

more troops from the $4^{\text {th }}$ and Shock Battalions, volunteers from the $128^{\text {th }}$ Mixed Brigade and a company of sappers. Four Companies of Assault Guards (Republican paramilitary police), believed at the time to have been sent to control the POUM's «suspect» troops, were kept in reserve. The capturing of the Loma de las Martires proved to be one of the few objectives taken during the offensive and the closest that Republican forces ever got to Huesca. Given the position was exposed to fascist machine gun and artillery fire from its flanks (Loma Verde and Loma del Manicomio) it is probable that an attack was not expected on the Loma de las Martires. With the failure of the offensive elsewhere, the fascists could concentrate their firepower on the taken position. Artillery and air bombardment and repeated assault by fascist troops, including Moroccan and Foreign Legion units, gradually wore down the defenders. Repeated calls for air or artillery support from Rovira brought few results. After holding out for three days the $29^{\text {th }}$ Division troops were given the order to retreat. The fascist forces had used 100,000 cartridges and suffered heavy casualties in retaking the position. ${ }^{72}$ Retreating the POUM militia was exposed to withering fire. It is unknown how many international volunteers were among the three hundred troops that lost their lives. One of the dead was the head of the $29^{\text {th }}$ Division's General Staff Camillo Lanzilotta, who probably had been sent to help evacuate the besieged militia after the $129^{\text {th }}$ Mixed Brigade's commander Amadeu Cahue had been killed. ${ }^{73}$

72. $5^{\circ}$ Cuerpo de Ejército, División 51 E.M. 2 ${ }^{\text {a }}$ y $3^{a}$ Sección, «Ataques realizados en el frente de la División en los días 12 al 19 de junio» AHM Caja 2100,18.; «Jefe Estado Mayor del Ejército del Este al Jefe Estado Mayor Central Coronel Rojo» 16.6.37. CDMH Incoporados 688; Coronel Jefe Frente a Jefe Operaciones Estado Mayor Central - «Parte de novedades del día 20 de junio 1937» Sariñena 20.6.37. CDMH Incorporados 688; Diario de Operaciones del Mehal-la Jalifiana del Rif n5, AHM Caja 2682,21; COLL, op cit. pp189-200; ARCARAZO, op.cit. p305.

73. Republican sources stated the POUM forces suffered $40 \%$ casualties, Coronel Jefe Frente a Jefe Operaciones Estado Mayor Central - «Parte de novedades del día 20 de junio 1937» Sariñena 20.6.37. CDMH Incorporados 688; Political Commissar Josep Pané, who took part in the fighting, claimed they lost «half» of their troops, COLL, op. cit. p196; according to Orwell «four to six hundred» were killed, ORWELL, op.cit, p288; the JCI gave a figure of three hundred, Juventud Obrera 12.7.37. 
General Sebastian Pozas, Commander of the Army of the East, congratulated Rovira on «the courage and brilliant behaviour» of the forces under his command. Such congratulations were short lived and the $29^{\text {th }}$ Division was withdrawn from the front line pending its dissolution. Shock Battalion troops nearly clashed with PSUC forces when they were sent to seize the $29^{\text {th }}$ Division's Transport Depot in Velillas. The taking of some of the POUM officers as hostages forced the Shock Battalion to surrender. The $29^{\text {th }}$ Division was formally disbanded on 17 July. Rovira and some other officers had already been arrested. Many of the former POUM Division fought on until the end of the war in other units. ${ }^{74}$

\section{Repression and counterrevolution}

With the suppression of the POUM and the dissolution of the $29^{\text {th }}$ Division the fate of its foreign volunteers was mixed. Those who were not arrested either left Spain or were integrated into other units, including the International Brigades. ${ }^{75}$

It has been possible to identify seventy foreign volunteers, forty of them German, who were arrested after the May events and in the weeks following the illegalisation of the POUM and the dissolution of the $29^{\text {th }}$ Division. Most of the party's foreign collaborators in the rearguard were also detained. The KPD's Defence organisation (KPD Abwehr) played a decisive role in this repression, drawing up reports on the POUM's German contingent and participating in interrogations along with Spanish police and NKVD agents. «Trotskyists», in the context of the Stalinist terror in the USSR, were automatically considered to be fascist agents and spies. Included in this category were all communists and left socialists who were critical of the official Communist Parties. Members of the KPD(O) in particular were singled out as «Gestapo agents» «spies» and «terrorists».

However, the Communists aim to launch a Moscow style purge in the Republican zone was undermined by their lack of total control over the state. Soviet foreign policy still aimed at forging an alliance with the Western democracies. Complete control of the

74. COLL, op.cit, p198; Guarner later testified to the 29 Division's «splendid conduct» in their defence of the Loma de la Martires, Proceso op.cit. p410; on the dissolution of the $29^{\text {th }}$ Division see: «Informe de las divisiones 25, 26, 28 y 29 del Ejercito del Este, presentan al Subsecretario de Tierra, del Ministro de Defensa Nacional, para su resolución en justicia» Azlor (Huesca) unsigned 3.7.37, Fundación Anselmo Lorenzo. The JCl's clandestine paper Juventud Obrera regularly carried obituaries to its fallen comrades on different fronts also see the manifesto «Les combatants du POUM a la clase ouvière mondiale» Les Combattants du POUM (Front du Levant, Front de l'Est, Front d'Estremadura, Front du Centre, julliet 1938) (Biblioteca de la Republica, Barcelona).

75. It has been possible to identify forty-four POUM volunteers who served with the International Brigades. The Germans Karl Schneider-Neuser, Walter Theis and Otto Töwe were considered suspicious as former POUM militiamen and imprisoned by the Brigades. 
Republic was not in Stalin's interests. Even though hundreds of POUM members were imprisoned, and several dozen, including Andreu Nin and Kurt Landau murdered, the actual mechanisms of repression proved contradictory if not inefficient.

Although there is no further trace of some of the foreign volunteers who were arrested only one, Bob Smillie, is known to have died in suspicious circumstances. Political Commissar of the ILP Contingent, Smillie was detained when crossing the border on 11 May. Imprisoned in Valencia, he died on 11 June, supposedly due to appendicitis, for which he had not received treatment. ${ }^{76}$ Of the POUM's foreign militia who were arrested most were accused of treason, often of being agents of the Gestapo or the OVRA. But few were actually sentenced. An exception was Gaston Ladmirall of the French Socialist Party who was sentenced to death but finally expelled from Spain after the intervention of the French Consulate. Walter Schwarz, despite being accused of high treason, was only sentenced to six years imprisonment. He later escaped.

The international campaign of solidarity organised by the IBRSU also put pressure on the Republican authorities. Three international delegations of prominent European labour leaders and lawyers, headed by ILP MPs, visited Barcelona in the months following the illegalisation of the POUM. Foreign prisoners, including former anarchist and POUM militia, launched a hunger strike in November 1937 to draw attention to their plight.. ${ }^{77}$

Some of those detained were released after a few weeks and expelled from the country. Others after being released were even reintegrated into the army. Among those released was Reiter who, despite being described by the KPD Abwehr as a «Gestapo agent and terrorist», finished the war with the rank of Major and as commander of the 97 Mixed Brigade. ${ }^{78}$ The rest remained imprisoned, and were either expelled during 1938 or, like the POUM leadership held in Barcelona's Modelo Prison, managed to escape just before the fascists entered the city on 26 January 1939. A handful went into hiding and secretly crossed the border in the following months.

A case apart was Georges Kopp, who was arrested on 20 June accused of being an enemy agent. According to Orwell, Kopp had travelled to the rear in order to transfer to another unit. What Orwell was unaware of is that Kopp appears to have been appointed to the General Staff of the XII International Brigade, with the rank of Captain. He may well

76. BUCHANAN, T., «The Death of Bob Smillie, the Spanish Civil War, and the Eclipse of the Independent Labour Party» The Historical Journal Vol. 40, No. 2 (Jun., 1997), pp. 435-461; NEWSINGER, J., «The Death of Bob Smillie» The Historical Journal 41, 2, 1998, pp575-578.

77. On the hunger strike see PAGĖS, P., La presó model de Barcelona. Història d'un centre penitenciari en temps de Guerra (1936-1939) (Barcelona 1996) pp389-390; on the delegations and of prisoners' conditions: La Batalla 11.9.37; 25.9.37; 2.10.37; 20.12.37; 6.1.38; «The Red Aid of the POUM» Report of the Foreign Delegation of the POUM in Paris, August 1938 (Biblioteca del Pavelló de la Republica, Barcelona).

78. RGASPI Opis 6/359; on Reiter and the $97^{\text {th }}$ Mixed Brigade see: CDMH, PEST 329, Exp 21392, Fol 2; CDMH, PEST 337, Exp 21934, Fol 2. 
have already joined his new unit as he told Orwell he had been fighting around Chimillas, where the XII had seen action the days before Kopp arrived in Barcelona. It is also strange, given the accusations being directed at the POUM, that Kopp, who had been one of its militia's leading officers, would be accepted onto the Brigade's General Staff. ${ }^{79}$ His sudden arrest could well have been due to the denunciation by a British volunteer Frank Frankford that Kopp had maintained contacts with the enemy at the front. ${ }^{80}$ Another former militiaman who gave evidence against the POUM was the Swiss Emile Bannhart who was arrested for spying in October 1937 and subsequently denounced the POUM of forming part of the Fifth Column. He was freed in January 1939.81

Kopp would later claim to have been interrogated twenty-seven times in one hundred and thirty-five hours by Russian agents. When he refused to sign a statement saying the POUM were spies, according to Kopp, he was put in a coal hole full of rats for twelve days with no food and told he would be shot. He was released in December 1938 without charges and without a judge's order. It remains unclear whether this was due to the intervention of the Belgian authorities, international solidarity or to other, as yet unknown, factors. ${ }^{82}$

Kopp's case highlighted the poor conditions in which anti-fascist prisoners were held in makeshift jails and Chekas. Subjected to particularly bad treatment were the members of the Trotskyist «Bolshevik-Leninist» group falsely accused of murdering the Polish NKVD agent Leon Narwicz in February 1938. Two former POUM militiamen, the Italian Trotskyists Domenico Sedran and Luigi Zannon were among those tortured. ${ }^{83}$

Not a single case of espionage was proven. The only possible spies known to have been in the POUM's ranks probably worked for the Communists, such as was the case

79. Kopp as «Capitán, Estado Mayor, XII Brigada Internacional», Albacete 7.7.37. (CDMH Serie Militar, Carpeta 1061-2, Fol 92) and 17.7.37. (CDMH Serie Militar, Carpeta 1061-3 [no fol]); on Kopp and the fighting around Chimillas: ORWELL op.cit. p325

80. Frankford had been arrested with another member of the ILP contingent, James Cope, for stealing paintings. Franford's accusations were widely reported in the Communist and International Brigade press, for example: Daily Worker 14.6.37, 16.6.37; The Volunteer for Liberty 13.9.37; SORIA, G., Trotskyism in the Service of Franco (London 1938) pp.40-42; Frankford very belatedly admitted he had lied: J. Meyers «Repeating the old lies» The New Criterion 1999 http:// www.orwell.ru/a_life/Spanish_War/english/e_olies

81. HUBER, P., Los voluntarios suizos en la guerra civil española (Guadlajara 2011) pp125-127.

82. ORWELL, op.cit. pp324-325; WILDEMEERSCH op. cit. pp63-66; «El nuevo crimen que se prepara; Jorge Kopp» La Batalla 6.11.37. Solidaridaridad Internacional Comité de Ayuda del POUM (Paris) $\mathrm{n} / \mathrm{d}$. (1938) says he was released he on 20 December.

83. Narwicz, an officer in the International Brigades, had infiltrated the POUM posing as a Russian dissident; he was executed by a POUM action squad in revenge for death of Nin, GUILLAMON, A., El terror estalinista en Barcelona 1938 (Barcelona 2013) pp269-301; Zannon, whose parents were Italian, was born in Barcelona. 
with David Wickes, who was with the ILP's medical services or the Germans Martin Schneider and Werner Schwarze. ${ }^{84}$ One exception was the mysterious Vinzenz Eberle, who may have been with the POUM's Cavalry, who was later accused of being a Gestapo agent by the KPD Abwehr; but despite being arrested three times between 1937 and 1938 he was always released. ${ }^{85}$

\section{The struggle continues}

With the Republic defeated and the advent of the Second World War, many of the former international volunteers faced a new period of great uncertainty. A few Jewish volunteers stayed on in Spain, fearing that exile would only lead them to a certain death. This was the case for instance of the doctor Charlotte Margolin and Reinhold Hoffmann, who had also served as an officer in the International Brigades. ${ }^{86}$

Many of those from countries with authoritarian regimes were imprisoned, along with tens of thousands of Republican combatants, in appalling conditions in the concentration camps hurriedly established by a hostile French government. Most were sent to the camps in Argelès-sur-Mer or Gurs where 6,808 International Brigade combatants were held. Even in their common suffering, the Stalinist campaign against the «Trotskyist fascists» continued unabated. In Gurs former POUM combatants joined with anarchist prisoners in opposition to the Communist dominance of the camp.

With the German occupation of France, the plight of the former volunteers worsened. Often those who had avoided the camps, and were living precariously in France, were now rounded up. Most of the Italians were expatriated to prisons in Italy, particularly on the islands of Ventotene and Tremeti. Others, especially those of Jewish origin, were sent to Nazi concentration camps where they invariably perished; as was the case with the Germans Herbert Büchner, the SAPD member Franz Gerstner and the Trotsky-

84. BOWKER, G., George Orwell (London 2003) p220; Schneider was a deputy in Reichstag in 1924 and later a Soviet citizen, he was later denounced by the KPD Abwehr as a «Gestapo» agent and of having «probably» been in the POUM militia, he disappeared in 1938, ABEL, op.cit, p454; ; Swarze was supposedly an agent of the KPD in the Cadre Commission of the PSUC and worked inside the «International Battalion» of the POUM, ibíd p470.

85. Eberle disappeared in July 1939 after supposedly reporting to the German Embassy in Paris; ABEL, op.cit., p127.

86. Margolin was arrested for eight days by the Francoist police in June 1940, after which there is no trace of her; Hoffmann was arrested in 1943; subsequently released he went to live in Italy in 1946. Another former POUM volunteer the Pole Abraham Lichten was listed among five thousand Jews in the Barcelona capital in 1945, http://www.mozaika.es/el-exilio-judeoasquenazien-barcelona-1933-1945-un-rompecabezas-que-pide-ser-resuelto/; http://pares.mcu.es/ParesBusquedas/servlets/Control_servlet. 
ist Rudolf Steffens, the Austrian Oswald Wilhelm, the Belgian Trotskyist Pierre Schavitz, the Dutch RSAP militant Theo Van Driesten and the Italian Trotskyist Guido Lionello, who died days after being liberated from Dachau. Others, like the Austrian Franz Ortner, the Belgian Trotskyists Florent Galloy, Camille Loots and Pierre Wouwermans, the French Trotskyist Georges Fournié and the Italian Bordigists Gildo Belfiore and Emilio Lionello survived the camps.

Other former POUM combatants, having escaped detention, joined the resistance, first in France, Holland and Belgium and later with the partisans in Italy. In France, the Austrian Rosa Winkler and the Italians Duilio Balduni and Giuseppe Bogoni, all PSMI members, formed part of the Fédérer et libérer resistance group. Gaston Ladmirall entered the resistance in 1941 and took part in the uprising in Paris in August 1944, as did the Bordigist Mario Bramati, who died in the fighting. The Trotskyists Pavel Thalmann and Guido Lionello also participated in the French resistance. In Holland various RSAP members who had fought with the POUM joined the resistance. PSMI member Estrucco Benci worked with the Trotskyist Domenico Sedran in the Belgian resistance. Benci was executed with two hundred other resistance fighters in January 1943. Many former POUM combatants freed from the Italian camps in 1943 joined the partisans or took part in the re-organisation of workers' movement in the liberated zone.

Former British and American militiamen joined their respective armies; as did some of those who had managed to go into exile. ${ }^{87}$ Benjamin Lewinski deserted from the Foreign Legion in Lebanon and joined the Free French Forces in Palestine. He went on to fight in North Africa, Italy and France. Hans Reiter, after passing through the terrible Morand prison camp in North Africa, also joined the Free French forces, becoming a sergeant in the famous $9^{\text {th }}$ Company of General Philippe Leclerc's $2^{\text {nd }}$ Armoured Division in which he distinguished himself in combat. On 24 August 1944 he was in command of the first of the $9^{\text {th }} \mathbf{s}$ halftracks to reach the Hotel de Ville. He later went with Leclerc to Indo China.

Georges Kopp, having returned to France from Britain in 1939, fought with the Foreign Legion. With the fall of France, after escaping from the Germans, he supposedly worked on making for petrol for the Vichy Regime, which he subsequently offered to the MI15. Kopp conditioned his collaboration on the basis of the British Secret Service sending him funds to pay off debts. In 1943 reports suggest he was by then working for MI5, albeit his exact relationship with them is unclear. ${ }^{88}$

87. The German Adolph Bresmann fought with the French Foreign Legion and eventually the British Army in North Africa; RSAP member Theo Jansen, after escaping from the Nazi labour organisation Todt in Norway, enlisted in the Dutch Princess Irene Brigade of the British Army; WIadamir Malacki and Giuseppe Pizzala also joined the French Army at the beginning of the war.

88. Once more the evidence about Kopp is highly contradictory, see WILDEMEERSCH, op. cit., pp77-90. 
With the end of the Second World War, many former POUM volunteers returned to political and trade union activities ${ }^{89}$ pre-war trades or in a few cases, revived their careers as writers and artists. Orwell, after enlisting in the Home Guard and working for the BBC during the war, now established himself as one of the world's foremost writers. Jean Malaquais (Malacki) published his famous novel Plànete sans visa about exile in Marseille during the war. Karl Heidenreich returned to painting, winning the 1961 Watercolour Prize. Benjamin Peret and Olga Loeuillet (Monskheli Preiss) remained active in the Surrealist movement. ${ }^{90}$

There is, however, no trace of scores of the former POUM international volunteers after 1939. War and repression had taken its toll. They and the cause they served deserve to be saved from oblivion.

89. For example Peter Blachstein returned to SPD and was a member of German Budestag from 1949 to 1968; the former leader of the ILP Contingent Bob Edwards was a Labour MP from 1955 till 1987.

90. For example Surrealisme, art moderne et art contemporain. Collection Olga Preiss Loeuillet 19072002 (París 2005). 
